\title{
Dictynna
}

Dictynna

Revue de poétique latine

9 | 2012

Varia

\section{Gods, Caesars and Fate in Aeneid 1 and \\ Metamorphoses 15}

\section{Bill Gladhill}

\section{Q OpenEdition}

Journals

Édition électronique

URL : http://journals.openedition.org/dictynna/820

DOI : 10.4000/dictynna.820

ISSN : 1765-3142

\section{Référence électronique}

Bill Gladhill, «Gods, Caesars and Fate in Aeneid 1 and Metamorphoses 15 », Dictynna [En ligne], 9 | 2012, mis en ligne le 11 janvier 2013, consulté le 11 septembre 2020. URL : http://journals.openedition.org/ dictynna/820 ; DOI : https://doi.org/10.4000/dictynna.820

Ce document a été généré automatiquement le 11 septembre 2020.

\section{(c) (i) (9)}

Les contenus des la revue Dictynna sont mis à disposition selon les termes de la Licence Creative Commons Attribution - Pas d'Utilisation Commerciale - Pas de Modification 4.0 International. 


\title{
Gods, Caesars and Fate in Aeneid 1 and Metamorphoses 15
}

\author{
Bill Gladhill
}

1 Ovid's reception of Vergil has enjoyed a fruitful and illuminating period of scholarly activity. This reception can be explored through subtle intertextual gestures between the Metamorphoses and Aeneid. At other times Ovid affects a full translatio of Vergil's great epic, such as in his playful Perseid and Thebaid, or in his "little Aeneid," which are so completely in conversation with Vergilian epic that Ovid leaves little doubt in his reader's mind the precise tradition he follows. ${ }^{1}$ In Ovid's formulation of "tradition" Greek epic has been retrospectively Vergilianized. When Ovid is not mining the Aeneid for poetic matters both large and small, he uses its unifying and unbounded vision of Roman power, as for example when he focalizes his poem's cosmology through Vergil's Venus and her lineage. The Metamorphoses even concludes with a heavy Vergilian rhythm. Ovid models the revelation of Caesarian Rome at Metamorphoses 15.745-842 on Aeneid 1.227-296, a passage that fuses fata with mythical (Aeneas) and historical (Caesar) deification. $^{2}$ The dialogue between the two texts at the end of the Metamorphoses is sustained, forceful and particularly curious. Vergil's great shadow moves over the finale of the Metamorphoses.

2 Scholars have long recognized that Ovid concludes his epic with Vergil's prophetic program of Aeneid $1 .^{3}$ At almost every moment of contact Ovid makes geographic alterations, chronological displacements, emotive and psychological additions, politically charged amplifications and suppressions. He includes what Vergil excludes (Caesar's assassination and Augustus' rise to power), and expands on the themes of deification and succession. While the Aeneid's largely positive prophecy (though some would disagree ${ }^{4}$ ) enfolds the tensions and ambivalent readings of the narrative into a synoptic macrocosm that authorizes the Julian teleology of Aeneas' colonization tale, Ovid's response extends the Aeneid's prophetic claims to include Augustus and his death. Ovid responds to imperium sine fine with finis imperii. In the Metamorphoses Ovid's fata have caught up with his tempora, as a prophetic future slips into an uncertain present, calling into question the entire narrative apparatus of prophetic poetics. I 
want to stress that Ovid is primarily interested in exploring the implications of Vergil's blending of Epic (arma virumque) with grand prophetic visions of Roman imperium and Caesarian encomiastic apotheosis. On one level, Ovid is standardizing a newly conceived Vergilian topos of prophetic poetics in the epic genre, which should be understood as an act of homage. On another level, Ovid raises serious questions about the utilization of poetic prophecy when any such "prophetics" are subject to reception and future manipulation. At the core of the poetic encounter between Metamorphoses 15 and Aeneid 1 is the suitability of encomiastic prophecy of contemporary figures in an epic tradition. ${ }^{5}$

3 The purpose of this paper is to provide an analysis of the poetics of Ovid's reception of Jupiter's prophecy in Aeneid 1 and to discuss the implications of Ovid's engagement with Vergil. At the end of the Metamorphoses Ovid explores the role of Vergilian prophetics in epic from a perspective that channels all the ways Vergil utilized fate, prophecy and divination into an ironic authorization of an Augustan present on the verge of ending. Whereas the Aeneid ends with the interpretative crux of the meaning of Turnus' death, Ovid's epic concludes with the imminent death of Augustus and the interpretative void his absence creates.

4 The narrative trajectory of the Metamorphoses conforms to a broad, global movement from gods' descending to the earth in order to cavort with demigods and mortals to the ascension of heroes and historical figures to live among the gods and the stars. ${ }^{6} \mathrm{Io} / \mathrm{Isis}$ (1.747), Callisto and Arcas (2.505-7), Ino and Melicertes (4.531-42), Bacchus (4.614), the Dioscuri (8.372), Hercules (9.239-72), Aeneas (14.581-95), Romulus (14.805-28), Hippolytus/Virbius (15.479-551), and Aesclapius (15.622-744) all undergo apotheosis through divine aid. Julius Caesar and Augustus undergo apotheosis, or will experience it, through a system of imperial succession. ${ }^{7}$ By the end of the epic there is a direct ticket to divinity, if imperial succession follows the model provided in the final book.

$5 \quad$ As the narrative directs itself to Italy and Rome Ovid gradually accelerates the cadence of deification. ${ }^{8}$ At the end of the Epic three deifications (Caesar, Augustus and Ovid) occur according to two interrelated systems of language : fata (Caesar/Augustus) and fama (Ovid). ${ }^{9}$ This heightened focus on apotheosis in Book 15 is accompanied by a more sustained concentration on prophecy and power than in any of the other books. ${ }^{10} \mathrm{At}$ the beginning of Book 15 Myscelos is told in a prophetic dream to desert his patriae sedes and establish a new city even though mors posita est patriam mutare volenti (15.29). Pythagoras, in his de rerum natura, based upon a fama that Rome will formam crescendo mutat (15.434), reports that Helenus (though he first gestures to vates who relate what the faticinae sortes say) foretold the founding of Rome and its domination by the Julian gens (15.439-49). Cipus, upon finding horns growing from his head, discovers by means of Etruscan haruspicia that he is fated (sic fata iubent) to be king and will rule safely with a sceptrum perenne (15.565-621), if he enters Rome (although he indicates in his contio to the Roman people that an augur would relay this prophecy if they sought it). ${ }^{11}$ The Romans consult the Delphic oracle in order to learn how to avert a plague, which results in further prophetic guidance through dreams and finally in the acceptance of the cult of Aesclapius into Rome. This sustained prophetic narrative-curiously merging fama and prophetic access to fata-is followed by Jupiter's "reading" of the tabularia fatorum to Venus at the moment of Caesar's assassination and catasterism. As Ovid brings the narrative closer to mea tempora, his narrative strikingly is catalyzed by a prophetic impetus. 
6 This increased use of prophetics climaxes at the end of the poem where Ovid has merged the prophetic program of the Metamorphoses with that of the Aeneid. Ovid draws a contrast between Julius Caesar in the Metamorphoses and the opening scene of the Aeneid in which Venus supplicates Jupiter on behalf of Aeneas. In the Aeneid Jupiter calms her by revealing the fata of Rome from the deification of Aeneas to the deification of Julius Caesar. In the Metamorphoses, on the other hand, at the moment of Caesar's assassination, Venus anxiously prays to the gods for help. Rather than offering aid they send prodigies to Rome. Here, Ovid directs his reader to another Vergilian episode, the signa scene of Georgics 1.461-514, which describes the response of the natural world to Julius Caesar's assassination. ${ }^{12}$ Jupiter then enters the narrative, revealing that Caesar's assassination is necessary for his consequent apotheosis, Augustus' pacification of the Roman world and future deification. But the very inscribed fata Jupiter recounts gestures to Georgics 2.490-522, a narrative about lapsarian states and the role of inscribed law in manifesting the Iron Age. If the inscribed fata of the Metamorphoses are physical manifestations of the Iron Age, then a tension is created if one suggests, as Anchises does at Aeneid 6.791-2, that Augustus Caesar, divi genus, aurea condet/ saecula, a phrase Ovid spells out at 15.832-33 : pace data terris animum ad civilia vertet/ iura suum legesque feret iustissimus auctor, lines which also recall Hesiod's formulation of the return of the Golden Age under the leadership of just kings (WD 225-37). How can there be any regeneration of a Golden Age if the fates themselves are products and embodiments of the Iron Age?

7 In looking at the general trend of Metamorphoses 15, then, it becomes clear that human prophetics in the form of dreams and oracles have yielded to divine prophecy. But this divine prophecy is constrained by fata, and even more significantly by fata as formulated by Vergil in the Georgics and Aeneid. Significantly, Ovid has channeled divine prophecy and fate back to the prophetic voice of the Vergilian vates. Ovid expands on Vergil's lines almost in the manner of a scholiast's marginal notes or commentary. A comparison of the prophetics of Aeneid 1 and Metamorphoses 15 show a great deal of overlap, but Ovid magnifies Vergil's prophecy, while also offering his own rendering of the lines' implied meaning.

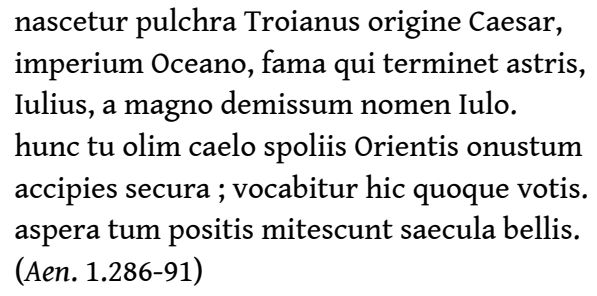

The first three lines of the Aeneid passage are a tour de force of Vergilian geo-poetics and -politics. Troianus shifts our perspective east and to aitia (origine). Four syllables later Caesar snaps it back west to Rome..$^{13}$ This movement from East to West, from past to future in the naming of Troianus Caesar is then modified by the subordinate clause to include Oceanus, which effectively changes the audience's perspective from Troy and Rome into the conception of a space completely bounded by the frontier limits of Oceanus in the Homeric sense (or Catullan : Oceanusque, mari totum qui amplectitur orbem 64.30), which then extends further to the stars as the line concludes. ${ }^{14}$ Yet, the far periphery of Oceanus and astra are framed by the hyperbaton Caesar...Iulius, setting the frontiers of the terrae and caelum within the name of a single man. The reorientation continues as Roman Iulius derives from Trojan Iulus. Iulius and Iulo frame the line, again 
shifting the reader's perspective in simultaneous snaps between East and West with hardly any differentiation between them, while mixing past, present and future, transforming the boundaries and expanses of space and time to mere shifts of perspective and alternative view points that collapse, condense and blur large stretches of physical space, morphing them into terminology, amalgamation and assimilation. But the extent of Caesar's fame is replaced by the man himself upon his apotheosis as he ascends spoliis Orientis onustus; the phrase is another way of calling him Troianus. Caesar has reconnected Troia and Roma. The spolia should not be interpreted strictly as booty taken in war and triumph, but the idea of Asia and Egypt more generally, its wealth, lands, peoples, all of those aspects of the landscape that had become part of Rome from the time of Sulla to Octavian. ${ }^{15}$

9 Vergil focuses on three aspects of Caesar : his Trojan origins (nascetur pulchra Troianus origine Caesar...Iulius, a magno demissum nomen Iulo), the spatial encompass of his power and fame (imperium Oceano, fama qui terminet astris...spoliis Orientis onustum) and his apotheosis and cult (hunc tu olim caelo...accipies secura; vocabitur hic quoque votis). Metamorphoses 15.746-51 reads like an exegesis of these lines.
Caesar in urbe sua deus est. quem Marte togaque
praecipuum non bella magis finita triumphis
resque domi gestae properataque gloria rerum
in sidus vertere novum stellamque comantem,
quam sua progenies; neque enim de Caesaris actis
ullum maius opus quam quod pater exstitit huius.
scilicet aequoreos plus est domuisse Britannos
perque papyriferi septemflua flumina Nili
victrices egisse rates Numidasque rebelles
Cinyphiumque Iubam Mithridateisque tumentem
nominibus Pontum populo adiecisse Quirini
et multos meruisse, aliquos egisse triumphos,
quam tantum genuisse virum, quo praeside rerum
humano generi, superi, favistis abunde!

(Met. 15.746-59)

Ovid's Caesar is constructed according to Vergil's tripartite structure : the lines include his birth and origin, the spatial encompass of his power and his apotheosis, which is actually witnessed as the Metamorphoses continues. The prophecy in the Aeneid has become narrative in the Metamorphoses. Yet, each category is intertwined with the other, so while the line begins with the presence of a divus Caesar in urbe sua, Caesar's sidereal metamorphosis results from his res gestae militiae et domi and the actions of his progenies. Caesar's magnum opus was not his triumphal conquests or his domination of Rome itself, but that he was a father. The focal point of the passage is the central significance of the name Caesar and paternity in the acta Caesaris. ${ }^{16}$ While the Vergilian passage looks to the Trojan origins of Caesar, locating the narrative of the Aeneid in a Julian family tree, Ovid closes this vast genealogical gap between Iulus and Iulius with the single nomen Caesar.

11 Outside of Metamorphoses 1.201 (Caesareo...sanguine), line 15.746 is the first naming of Caesar in the poem, a moment of primacy that connects it to Aeneid 1.286, itself the first usage of Caesar in that epic. ${ }^{17}$ The subtle changes in naming perceived in Troianus... Caesar...Iulius...Iulo have been completely submerged in the nomenclature Caesar... Caesaris. While Vergil gives voice to a mythical fiction in merging Iulus and Iulius, Ovid's doubled Caesar masks the "imperial fiction" of a perfectly closed loop of 
succession..$^{18}$ We could understand the granting of the title Caesar as a horizontal transaction from father to son. Jupiter, on the other hand, offers a vertical transaction, one that stresses Julian-and therefore Venereal-lineage at Met 15.841-2 in his pronouncement that there will be an aedes divi Iulii (ut semper Capitolia nostra forumque/ Divus ab excelsa prospectet Iulius aede). ${ }^{19}$

12 The joint effort of the father-son duo to inscribe Julius' divinity into the sky is glossed as acta Caesaris, a phrase whose ideology both looks back to Cicero, who seems to have coined the phrase (fully working out its legal implications in the Philippics), and the first author to use the phrase after Cicero, Ovid, who includes it three times in his works, once in reference to Julius (the present case) and twice in reference to Augustus. 20

13 Yet, with the lines, quam sua progenies; neque enim de Caesaris actis/ ullum maius opus quam quod pater exstitit huius Ovid isolates Augustus within the entire expanse of Vergilian prophetic time, as the line looks to Aeneid 6.790-91 of Anchises' speech : hic Caesar et omnis Iuli/ progenies magnum caeli venutra sub axem. Omnis progenies has given way to sua progenies. ${ }^{21}$ The grand prophetic vision of Anchises in Aeneid 6 is contrastive with Vergil's antiquam exquirite matrem./ hic domus Aeneae cunctis dominabitur oris/ et nati natorum et qui nascentur $a b$ illis at Aen. 3.96-8, itself a reformulation of Iliad 20.307-308

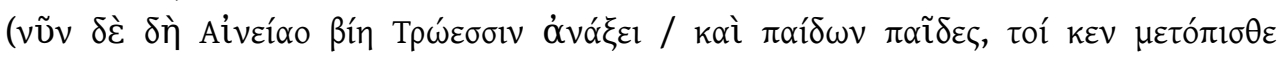
$\gamma \varepsilon ́ v \omega v \tau \alpha \mathrm{l})$. Vergil linked the prophetic authority of Neptune in Iliad 20 to Apollo's oracular pronouncement in Aeneid 3. Aeneas and his descendants are the focal points of each prophecy. At Aeneid 6, however, the prophetics takes a contemporary turn to focus on the offspring of Caesar, in essence channeling the Iliadic claim through Julian Rome. Ovid follows the prophetic trajectory of the Iliad and Aeneid, but he caps Neptune's paides, Apollo's nepotes and Anchises' omnis progenies with the singular Augustus, who became sua progenies through the acta Caesaris.

14 The Ciceronian force of acta Caesaris situates the reader within the political discourse of Republican Rome, post-assassination, and in the present context the adoption of Octavian is central for a clear interpretation of the phrase. It recalls the Republican valence the title Caesar experienced both during the dictatorship and during Octavian's power struggles. The name both validated the young man's claim to Caesar's property, which in Ovid could be construed as Rome itself (sua urbs), but it also became a sleight against Octavian, used by his competitors in their claim that the boy's position was owed entirely to a name. ${ }^{22}$ While a reader familiar with Cicero's Philippics might sense the Republican force of this phrase, Ovid suggests that Octavian had more than a mere "name." Caesar only became "Caesar" after Actium, after the defeat of the rival Antony. It could very well be the case that Actium is implied in the phrase acta Caesaris, which suggests that this battle was concerned with establishing a legacy of imperial adoption and succession.

15 Let us now turn to Ovid's commentary of Vergil's second category, the geopolitical force of Julius Caesar. Ovid filters imperium...onustum (Aen. 1.287-9) through Met. 15.752-59..$^{23}$ These lines are a continuation of the interplay between the Caesares discussed above, but here Ovid captures the cosmological consequences of Caesar's res and the "birth" of his son..$^{24}$ While Julius' res are plus in comparison to having given birth (genuisse) to a tantus vir (something he did in name only), it is Augustus himself (quo)-the praeses rerum-through whom the gods grant abundant favor to the human race. 
16 Ovid then unfolds like a map Vergil's imperium Oceano as he characterizes Caesar's conquest with clearly defined locations (aequorei Britanni [752] and Pontus [756]). Rather than the succinct and impressive imperi oceano, Ovid spatializes more directly and acutely the implications of Vergil's phrase, while connecting the semantics of Ocean to the limits of this imperium, construed in the adjective aequoreus and the seascape, Pontus. Of course, Pontus refers to the Black Sea and the Roman province of the same name. Through demarcating imperium with "sea-blue" Britain and Pontus Ovid has scaled back the claim of Oceanic imperium in Vergil and set it within the vocabulary of Roman provincial governance. This delimitation of Vergil's Oceanus corresponds to the bottlenecking of genealogical time through Augustus by Ovid. But between the imperial peripheries of Britain and Pontus lie Egypt and Numidia, two landscapes whose Pompeian and Catonian undertones are suppressed beneath the word rebelles and the phrase perque papyriferi septemflua flumina Nili/ victrices egisse rates (754-55). ${ }^{25}$ Caesar's journey up the Nile is charged with the imagery of triumph in egisse triumphos at line 757, but rather than driving chariots through the seven hills (septemmons/ septimontium) of Rome, the seven mouths of the Nile (septemfluaflumina emphasized by its seven syllables) find his victrices rates. ${ }^{26}$ Caesar's triumph over Pompey can only be celebrated outside of Rome in Egypt while his Roman triumphs must be cloaked in the guise of foreign conquest. Ovid fills the absent spaces of Vergil's imperium Oceano in a way that defines the spatial, historical and imperial reality contained in Oceanus. The fact that Ovid includes the regions of Pontus and Egypt at one instant reveals another element of spolia Orientis, as Ovid, like Vergil, has suppressed the civil war referents in characterizing Caesar's victory. Yet, this suppression is accompanied by revelation: Ovid's portrayal of Egypt as the location of Caesar's triumph depicts Alexandria not only as the locus of Civil War triumphs, but also as a potential Rome where triumph might be celebrated. Ovid, in effect, charges Vergil's onustum with an ironic valence ; Caesar became deified, laden with the "baggage" of his own Alexandrian affairs, especially when Caesar's triumphal pleasure cruise up the Nile was made with Cleopatra at his side. ${ }^{27}$ Even more, this baggage accompanies him to Rome in 46 where both Cleopatra and Caesarion remained until Caesar's assassination.

17 Ovid's expansion of and commentary on his epic predecessor have revealed the implications of "birth," nomenclature and power in Caesarian Rome. Ovid's commentary on Vergil's third theme-that of Caesar's divinity- raises important questions about his own reading of fata and poetic authority in the Aeneid. ${ }^{28}$ Caesar in urbe sua deus est is the perfective achievement of Jupiter's ameliorative utterance to Venus at Aeneid 1.289-90: hunc tu olim caelo spoliis Orientis onustum/ accipies secura; vocabitur hic quoque votis. ${ }^{29}$ Ovid's deification of Caesar comes in two parts. The first section focuses on Caesar's metamorphosis and the second part magnifies Jupiter's reassurance to Venus (accipies secura) in the Aeneid as Ovid includes in his epic Caesar's assassination.

18 The first representation of Caesar's apotheosis in the Metamorphoses is as follows, to reiterate :

Caesar in urbe sua deus est. quem Marte togaque

praecipuum non bella magis finita triumphis

resque domi gestae properataque gloria rerum

in sidus vertere novum stellamque comantem...

(Met. 15.746-49) 
Caesar's deeds in war and peace change him into a novum sidus and a stella comans, or to put it another way, into a celestial caesaries. ${ }^{30}$ Caesar transforms into his name, a metamorphosis that connects him to a whole class of characters in the poem whose names are self-referents to their novae formae, beginning with the poem's first metamorphosis Lycaon. ${ }^{31}$ That Ovid inserts Caesar into a broader pattern of transformation within his poem is only part of the story.

20 He also suggests another element to Caesar's deification that may explain the odd Romanization of the seven mouths of the Nile mentioned above. Ovid's Caesar is reminiscent of Catullus 66, a translation of Callimachus' coma Berenices included in Aetia 4 , a poem that plays with the notion of deification. ${ }^{32}$

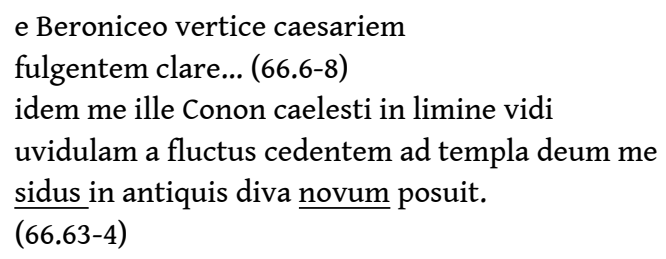

21 In Catullus 66 a caesaries becomes a novum sidus among old stars. In Ovid Caesar becomes a novum sidus. While Vergil burdens the deified Julius with spolia Orientis, itself a euphemism for Alexandrian spoils, Ovid fuses Caesar's catasterism with that of an Alexandrian queen's lock of hair. ${ }^{33}$

22 It has been long recognized that Callimachus' Lock of Berenice and the translation of it by Catullus stand behind the language of Caesar's apotheosis here. ${ }^{34}$ In fact, the final two books of the Aetia are significant models, if we follow Alessandro Barchiesi's point that Callimachus' Ektheosis Arsinoes provides the source for Venus' anxious supplication on behalf of her descendants. ${ }^{35}$ Barchiesi suggests that this reference (among others) reflects a "feminization of grand politics," in which Alexandrian images of power and monarchy are adapted to a Roman context where the "Aphrodisian ruler-cult" associated with Egyptian queens is transferred to Caesarian Rome. ${ }^{36}$ But is this the high water mark of the reference or is the focus on apotheosis and biological (progenies/ pater/genuisse) offspring indicative of more?

23 While Vergil privileges the image of Caesar as a proto-Augustan conqueror of Egypt, Ovid encourages a reading that does more justice to Caesar's ambiguous relationship with Cleopatra and Alexandria. Nearly midway through Book 15 Pythagoras states that fama reports Rome will undergo metamorphosis (mutat) and become immensi caput orbis. The cutting of Caesar and his connection to Berenice's caesaries extend the imagery of Rome's metamorphosis into a "head," as though the assassination of Caesar is akin to sheering Rome's hair. ${ }^{37}$ Maria Wyke points to a Sibylline Oracle (3.350-80) which states that a despoina "will exact Asia's vengeance for Roman aggression by shearing Rome's hair and, with that victory, usher in a Golden Age of peace for both Asia and Europe." ${ }^{38}$ The final metamorphosis of the poem seems to be a realization of this precise oracle. I do not want to push the parallel too far (and some reading will think I have done so already) and offer up a despoina here, but if Ovid is alluding to such an oracle, this would politicize even more paradoxically the feminization of power and apotheosis Barchiesi argues is at the core of Ovid's reference to the Lock of Berenice. The heavy rhythms of Alexandrian apotheosis suggest that Ovid is alluding to more than Alexandrian religious models of feminized power. The oracle suggests that Caesar's assassination is a requisite act for the return of a Golden Age, which Roman poetry 
connected to the advent of Augustus, the progenies of Caesar. The problem with this formulation is that Caesar actually produced a son with Cleopatra, Caesarion, whose birth was celebrated on Egyptian monuments where he was presented as her legitimate heir. ${ }^{39}$ In another sense, there was another "caesaries" which needed to be "cut" for Augustus' position to be completely solidified. But in performing this act Augustus practically commits an act of fratricide, one of the notable horrors of the Iron Age.

24 More than commenting on Vergil here, Ovid merged prophecy and fata with narrative, which results in actors within the poem responding to Vergil's prophetic trajectory. In this instance, Venus is made to witness Caesar's assassination. In anticipation of the event Venus struggles to hide Caesar in a cloud (tum Cytherea manu percussit utraque) pectus et Aeneaden molitur condere nube, Met. 15.803-4), mimicking her Iliadic subterfuge (qua prius infesto Paris est ereptus Atridae,/ et Diomedeos Aeneas fugerat enses, Met. 15.805-6). More significantly, Ovid characterizes the event in terms of Aeneid 1.33 : tantae molis erat Romanam condere gentem. The hiding of the Aeneis in a cloud is an intertextual gesture to the underlying implications behind Vergil's moles, the establishment of a poetically authorized Augustan Rome (Aeneaden molitur condere).

25 Jupiter stumbles on the scene in order to reveal the fata Caesaris. The most striking facet of the fata is not the historical chain of events linked to Caesar's assassination, but the fata themselves, who has access to them, where they are located, and what they are made of :

talibus hanc genitor : 'sola insuperabile fatum,

nata, movere paras? inter licet ipsa sororum

tecta trium ; cernes illic molimine vasto

ex aere neque et solido rerum tabularia ferro,

quae neque concussum caeli neque fulminis iram

nec metuunt ullas tuta atque aeterna ruinas.

invenies illic incisa adamante perenni

fata tui generis ; legi ipse animoque notavi

et referam, ne sis etiam num ignara futuri

(Met. 15.807-15)

Jupiter informs Venus that while she cannot movere fatum (as Jupiter actually does in Aeneid 1, then curiously redefines at Aen. 10.112-13, rex Iuppiter omnibus idem./ fata viam invenient), she can enter the tecta trium sororum where she will see (cernes, as at Aeneid 1.257-60) the bronze and iron tabularia rerum, adamantine objects, forever protected from and unafraid of ira fulminis and ruina. ${ }^{40}$ Rather than being assured that she "will see" an urbs, moenia and a deified Caesar, she can actually look upon the fata where she will find (invenies, perhaps a gesture to Aen. 10.113) the fata tui generis. ${ }^{41}$ The material of the tabularia rerum represent, as far as I know, the first time that fata are inscribed on a metal. Tabulae were, of course, smelted from bronze, and Ovid is clearly Romanizing traditional fata, inserting them into the context of Roman record keeping and administration. ${ }^{42}$ But this bold reconstitution of the tres sorores' material is part of a broader transformation in the ontology of fata themselves, their implications and relationship not only to human action, but also to divine knowledge.

Vergil seems to suggest that the fata Jupiter unfolds are written on the papyrus of a book roll. Ovid responds with fata inscribed in bronze and iron and stored in an Olympian tabularium. ${ }^{43}$ This change of medium for transcription has broader implications. Olympus is subject to urbanization. Catullus 64 may also play a role in this shift of materiality of the fata where the Parcae weave images of the fata. From Catullus 
to Ovid there is a progressive process of recording the fata, developing from weaving to writing on paper and from writing to inscribing on metal. Each stage of transcription may represent a greater trend towards Roman bureaucratic record keeping and administration. Paper to metal is accompanied by the tabularium, an urban space that was built at a relatively late date during the Roman Republic, which suggests that in the 1200 years since Aeneas' arrival to Italy, the gods themselves have been building Olympus on the model of Rome. The phrase tecta trium sororum sets the house of the fates among various other cosmological domiciles in the poem, such as Palatinian Olympus ${ }^{44}$, the Palace of the Sun, and the domus of Fama. ${ }^{45}$ In their connection to these houses the tecta-tabularia participate in the spatialization of the literary topography of the Metamorphoses in terms of Roman urban space: Olympus is mapped upon the Palatine, while the Palace of the Sun and the flight of Phaethon represent a cosmological Circus Maximus, and the domus of Fama is modeled on the Forum Romanum. ${ }^{46}$ At the end of the poem Ovid points to another monument, an Olympian tabularium where the gods are permitted to "read" and "make note" of the fata. ${ }^{47}$ That Venus is made aware only now that she could have discovered (invenies) the fata sui generis (what seems here to be like genealogical catalogue poetry) is a marker of the wholly novel building Ovid has constructed within his cosmography at the end of his poem.

28 The phrase solido rerum tabularia ferro has further implications. Towards the end of Georgics 2, Vergil describes the life of a fortunatus who has a pious respect for divinities and resides in a Golden Age. Vergil describes this age through negative examples :

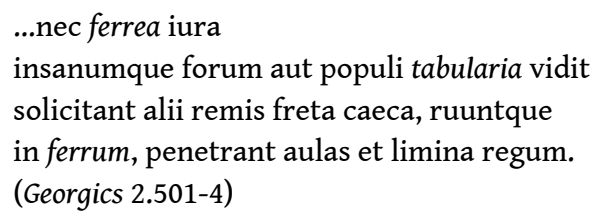

Tabularia is a rare word, used prior to Ovid only here. This point alone would be slight if ferrum were absent. Ovid's solido rerum tabularia ferro suggests that he has these lines of the Georgics in mind. In the Georgics, tabularia, coupled with ferrea iura ${ }^{48}$ (which would have been inscribed on bronze tabulae, not iron), and the various manifestations of wealth and luxury that accompany Iron Age society-and in particular civil strife and the type of migration one finds in Eclogue 1 (gaudent perfusi sanguine fratrum,/ exsilioque domos et dulcia limina mutant/ atque alio patriam quaerunt sub sole iacentem, Geo. 2.510-12) -signify the loss of the Golden Age through social discord and urban development. Ovid's description of the tabularia alludes to Vergil's Iron Age at the very moment when the Metamorphoses' narrative describes political competition, civil discord and assassination ${ }^{49}$ There is no need for Ovid to belabor the reference given the historical context of the narrative. The fates themselves are not only markers of the Iron Age, they are themselves artifacts of this Iron Age as they inscribe not only Caesar's assassination, but his apotheosis. Ovid is the first author to mark out deification as a fixture of the Iron Age in his Amores. ${ }^{50}$ It seems as if the Iron Age is now the defining temporal frame of Olympus, in which the language of Roman urban development and its attendant evils implicate the divine apparatus of the poem. ${ }^{51}$

30 Ovid's fata in the mouth of Jupiter mimick the Jupiter of Aeneid 1 as the god further reveals the syntax of Caesar's deification; it requires the nominis heres to bear the onus and to become an ultor with the gods as his allies. ${ }^{52}$ Jupiter then magnifies the onus the ultor will bear. Iterum Philippi suggests that Georgics 1.489-92 is the source of Jupiter's 
prophecy (ergo inter sese paribus concurrere telis /Romanas acies iterum uidere Philippi;/nec fuit indignum superis bis sanguine nostro /Emathiam et latos Haemi pinguescere campos). But in Ovid's expansion of the Georgics, the iterated Philippi becomes flanked by Mutinae on the one side and by Octavian's war with Sextus Pompeius and Antony-Cleopatra on the other:

illius auspiciis obsessae moenia pacem

victa petent Mutinae, Pharsalia sentiet illum,

Emathiique iterum madefient caede Philippi,

et magnum Siculis nomen superabitur undis,

Romanique ducis coniunx Aegyptia taedae

non bene fisa cadet, frustraque erit illa minata,

servitura suo Capitolia nostra Canopo.

(15.822-28)

of the series of battles Jupiter recounts, the only one that is connected to the heres nominis in his capacity as ultor is the very one present in the Georgics. It was at Philippi where Octavian (perhaps apocryphally) vowed a temple to Mars Ultor, which was finally dedicated in 2 BCE. ${ }^{53}$ Mutina immediately undermines Jupiter's framing of the material as it refers to a battle in which Octavian fought against Antony on behalf of the Republican side, prior to vowing a temple to Mars ultor. ${ }^{54}$ The war of vengeance is then broadened to incorporate Octavian's dealings with Sextus Pompey, the Romanus dux and his coniunx Aegyptia, who had threatened that she would enslave Jupiter's (nostra) Capitoline. Ultor is difficult to reconcile with the broader series of civil conflicts and their historical circumstances inscribed in the fata, especially when Fasti 3.705-10 clearly connects vengeance (ulcisci) to Philippi alone. ${ }^{55}$

But this seemingly inconsistent historical assemblage for ultor needs to be read according to the logic of the final episode of his poem. The Metamorphoses has emphasized that Caesar's deification is a sine qua non for Octavian's apotheosis. From this perspective Ovid's narrative runs parallel to the thematic dialogue between the Temple of Mars Ultor and the aedes Iulii, with each monument participating in Julian divinity. ${ }^{56}$ The battles that flank Philippi are validated by their ultimate trajectory in bringing to realization the apotheosis of Caesar and ultimately of Augustus. ${ }^{57}$

The transformation of Octavian into Augustus is subtly insinuated into the narrative as the ultor becomes an auctor: pace data terris animum ad civilia vertet/ iura suum legesque feret iustissimus auctor (Met. 15.832-33). And while iura and leges suggest that Augustus is acting as a lawgiver to a new state, the trajectory of this episode has already been conditioned on the sequence of Iron Age referents in tabularia ferro. The verb feret (not to mention the numerous uses of ferunt/feruntur throughout the final lines of Met. 15) is not neutral; it shades the pace data terris...civilia iura with an iron hue. ${ }^{58}$ But the lines above stop short of incriminating Augustus. Feret is the governing verb of iustissimus auctor, a relationship that depicts the fine line Augustus draws. The only thing standing between ferrum and the iustissimus auctor is a single $-\mathrm{r}-{ }^{59}$ Ovid seem to be following the word play between ferr/fer found most famously in Tibullus 1.10.1-2 (quis fuit, horrendos primus qui protulit enses?/ quam ferus et vere ferreus ille fuit!). It is implied in this line that the evils of the Iron Age are mitigated by the quality of the most just ruler, who, as early as Hesiod, could relegate the evils of the Iron Age to a manageable place. ${ }^{60}$

34 As Jupiter continues to recall his notes, human time seems to be moving at a rapid pace. The auctor is redefined as segnior. This renaming of Augustus recontextualizes the Iron Age backdrop since tacitly in any discussion of the Ages of Mankind is the passage 
from one epoch into another. The problem of an aging Augustus is that the period of peace and civil law will not remain static.

exemploque suo mores reget inque futuri temporis aetatem venturorumque nepotum prospiciens prolem sancta de coniuge natam ferre simul nomenque suum curasque iubebit ; nec, nisi cum senior Pylios aequaverit annos, aetherias sedes cognataque sidera tanget.

(Met. 15.834-39)

Caesar's apotheosis immediately follows these lines, as he becomes a iubar at the moment his body is cut (hanc animam interea caeso de corpore raptam/ fac iubar, ut semper Capitolia nostra forumque/ divus ab excelsa prospectet Iulius aede! $\left.!^{161}\right)$, but the fata reveal that Augustus will become an old man, and after he has reached the age of Nestor he will become a god. But he will govern the future mores by the force and authority of his exemplum. ${ }^{62}$

36 The idea of Augustus' exemplum stresses the need for the past in constructing a sustainable Roman future, precisely because Ovid's fata have merged with his tempora. Augustus is segnior. His apotheosis is at hand. For four years after the "publication" of the Metamorphoses (however, we want to imagine it), the end of the poem would have slipped seamlessly from the page into the living space of the audience, as Augustus grows older day after day, reading after reading. But just as in Aeneid 1 where Jupiter passes over the death of Julius Caesar, Ovid's Jupiter moves directly from Augustus' long life to his apotheosis, omitting that pivotal moment between the two events.

While Ovid follows Augustus' fated apotheosis with the actual deification of Julius Caesar, the transition from Augustus' future deification to Caesar's actual apotheosis is inherently problematic. The problem is twofold: the mode of deification established between the Caesares hinges on the name (heres nominis), and furthermore this new Caesar must bear the onus of being a progenies. The deification of the father is conditioned on the actions of the heres nominis. ${ }^{63}$ While Augustus will see his grandchildren, the phrase venturorumque nepotum/ prospiciens prolem sancta de coniuge natam/ ferre simul nomenque suum curasque iubebit entails all that is at stake in the choice of progenies and the name. Ovid captures the precipitous balance between feret (iustissimus auctor) and ferrum, by moving one step closer to the full realization of the Age of Iron as it hangs upon the ferre, that is the ability of Augustus' successor to bear the nomen and the curae. An unsuccessful successor will bring the Iron Age world of Roman Civil War. Another Iterum...Philippi is not precluded if Augustus' example is not followed.

38 Myths and narratives of succession should not end epics, but here at the end of the Metamorphoses Ovid emphatically sets the transition from Julius to Augustus within the myth of succession: sic magnus cedit titulis Agamemnonis Atreus, Aegea sic Theseus, sic Pelea vicit Achilles...sic et Saturnus minor est Iove (Met. 15.855-58). ${ }^{64}$ Is Augustus like the heroes or Jupiter? The difference matters. Agamemnon, Theseus and Achilles invoke the Orestes, Hippolyti, and Neoptolemi, the tragic successors of their tragic fathers. Jupiter is unique in that he ends succession myths completely on the divine level. It is precisely this reason why Ovid refers to Georgics 1.497 (di patrii Indigetes et Romule Vestaque mater ${ }^{65}$ ) in which Vergil prays that the gods allow the iuvenis to succor his inverted age on the premise that the perjury of Laomedon has been repaid with Roman blood. ${ }^{66}$ Ovid's prayer both includes the Georgics as a subtext, but it focuses on Augustus at the 
threshold of divinity. ${ }^{67}$ Ovid calls upon the gods to delay Augustus' death and that, when it does arrive, he might favor those who are praying. (tarda sit illa dies et nostro serior aevo,/ qua caput Augustum, quem temperat, orbe relicto/ accedat caelo faveatque precantibus absens, 15.867-70). The final clause, faveatque precantibus absens, recalls Met. 15.758-9, which connect the favor of the gods to the presence of a praeses rerum (quo praeside rerum/ humano generi, superi, favistis abunde). Just as Caesar's res hinged upon his successor, so too do Augustus', but the poem and the fata leave the nomen of the heres nominis absent. Instead, the divine Augustus still inhabits the space of the praeses rerum, although his deification (i.e. death) will leave an absence (absens) in Rome, which will necessitate a new praeses rerum. Ovid has filled this uncertainty with the hard reality that even when an emperor is iustissimus the Iron Age is lurking beneath his leges and iura civilia. The superlative does not lend an optimistic reading to the success of a successor that he become even more just than the prior auctor. Succession is suppressed, but its tensions and fears are fully tangible. Ovid's gesture to the Georgics emphasizes all the more just how precariously the matter hangs as the iuvenis in the Georgics is now segnior in the Metamorphoses.

The final episode of the Metamorphoses ends in a state of uncertainty in the context of succession after a long realignment of Vergil's fata in Aeneid 1. The poem concludes with the parenthesis si quid habeat veri vatum praesagia (15.879). The conditional captures the central issue at stake in Ovid's dialogue with Vergil; do the praesagia vatum have any claim to truth and how do we know ${ }^{68}$ The wit and humor of the epic's finale with its anxious Venus, clumsy Jupiter, and tabularium fatorum give way to the serious intellectual and poetic engagement between Ovid and Vergil and the question it raises about praesagia vatum. This is serious poetics as the narrative slips from imperial encomia to the unpredictability of succession. The push and pull of destiny as shaped by Vergil become a cosmological crisis in Ovid as fata appear to give way to acta Caesaris and gods become passive observers of a new system of apotheosis based wholly on the title Caesar.

\section{BIBLIOGRAPHIE}

Adamik, T. 1999. "In speciem unius corporis : Struktur und Botschaft von Ovids Metamorphosen," in Schubert ed., Ovid und Wirkung : Festgabe für Michael

Von Albrecht zum 65. Frankfurt : 257-68.

Ahl, F. 1985. Metaformations : Soundplay and Wordplay in Ovid and Other Classical Poets. Ithaca. Austin, R.G. 1971. Aeneidos Liber Primus with Commentary. Oxford.

Ball, A. 1913. “Julius or 'Julius' : A Note on Verg. Aen. 1.286ff," AJPh 34 : 81-84.

Barchiesi, A. 1997. “Endgames : Ovid's Metamorphoses 15 and Fasti 6 in Roberts, Dunn, Fowler eds., Classical Closure : Reading the End in Greek and Latin Literature. Princeton. 
--1999. "Ovid and the Homeric Hyms," in Hardie, Barchiesi, and Hinds eds., Ovidian Transformations : Essays on the Metamorphoses and its Reception. Cambridge : 112-26.

--2001. Speaking Volumes : Narrative and Intertext in Ovid and other Latin Poets. London.

--2009. "Phaethon and the monsters" in Hardie ed., Paradox and the marvellous in Augustan literature and culture. Oxford.

Bettini, M. 2008. “Weighty Words, Suspect Speech : Fari in Roman Culture," Arethusa 41 : 313-75.

Bömer F. 1959. “Ovid und die Sprache Vergils," Gymnasium 66 : 268-87.

--1986. Metamorphosen : Kommentar Buch 14-15. Heidelberg.

Bosworth, B. 1999. “Augustus, the Res Gestae and Hellenistic Theories of Apotheosis," JRS : 1-18.

Buchheit, V. 1963. Der Anspruch des Dichters in Vergils Georgika : Dichtertum und Heilsweg. Darmstadt.

Dobbin, R. 1995. “Julius Caesar in Jupiter's Prophecy, Aeneid Book 1,” CA 14 : 5-40

Döpp, S. 1969. Virgilischer Einfluss im Werk Ovids. Munich.

Due, O.S. 1974. Changing Forms: Studies in the Metamorphoses of Ovid. Copenhagen.

Feeney, D.C. 1991. The Gods in Epic : Poets and Critics of the Classical Tradition, Oxford.

Feldherr, A. 2010. Playing Gods : Ovid's Metamorphoses and the Politics of Fiction.

Princeton.

Franke, W. 2005. "Virgil, History and Prophecy," Philosophy and Literature 29 : 73-88.

Galinksy, G.K. 1975. Ovid's Metamorphoses : An Introduction to the Basic Aspects. Berkeley.

Gladhill, C.W. 2013. "Republican Cosmology and the Domus of Fama in Ovid's Metamorphoses," in Nelis and Farrell eds., Augustan Poetry and the Roman Republic, Oxford.

Griffith, J. 1978. “The Divine Audience and Religion in the Iliad," CQ $28: 1-22$.

Gurval, R. 1997. "Caesar's Comet : The Politics and Poetics of an Augustan Myth," Memoirs of the American Academy in Rome 42 : 39-71.

Hardie, P. 1986. Virgil's Aeneid : Cosmos and Imperium, Oxford.

--1990. “Ovid's Thban History : The First “Anti-Aeneid, ?” CQ 40 : 224-35.

--1993. The Epic Successors of Virgil : A Study in the Dynamics of Tradition. Cambridge.

--1997. "Questions of authority : the invention of tradition in Ovid's Metamorphoses 15," in

Habinek and Schiesaro eds., The Roman Cultural Revolution. Princeton : 182- 98.

Heinze, R. 1915. Virgils Epische Technik. Leipzig.

Hejduk, J. 2009. “Jupiter's Aeneid : Fama and Imperium," CA 28 : 279-327.

Hinds, S. 1987. “Generalizing about Ovid," Ramus 16 : 4-31.

Holleman, A.W.J. 1969. “Ovidii Metamorphosen liber 15.622-870 (carmen et error)," Latomus 28 : $42-60$.

Knox, B. 1986. Ovid's Metamorphoses and the Traditions of Epic Poetry. Cambridge.

Kraggerud, E. 1992. “Which Julius Caesar ?," SO 67 : 103-112.

--1994. “Caesar versus Caesar Again : A Reply," SO 69 : 83-93. 
Lamacchia, R. 1960. “Ovidio interprete di Virgilio,” Maia 12 : 310-30.

Lyne, R.O.A.M. 1974. "scilicet et tempus veniet...Virgil, Georgics, 1.463-514," in Woodman and West eds., Quality and Pleasure in Latin Poetry. Cambridge : 47- 66.

Maleuvre J.-Y. 1991. “Ovide Revisité : La Satire Politique Dans Les Deux Derniers Livres Des Métamorphoses," Pallas 37 : 89-103.

--2005. Vrais et faux héros dans les Métamorphoses d' Ovide. France.

McKeown, J.C. 1984. “Fabula Proposito nulla tegenda meo : Ovid's Fasti and Augustan Politics in Woodman and West eds., Poetry and Politics in the Age of Augustus. Cambridge : 169-88.

Meyer, E. 2004. Legitimacy and Law in the Roman World : Tabulae in Roman Belief and Practice. Cambridge.

Newman, J.K. 1967. The Concept of Vates in Augustan Poetry. Brussells.

Nisbet, R.G.M. and M. Hubbard. 1978. A Commentary on Horace : Odes Book II. Oxford.

O'Hara J. 1990. Death and the Optimistic Prophecy in Vergil's Aeneid, Princeton.

--1994. “Temporal Distortions, 'Fatal' Ambiguity, and Iulius Caesar at Aeneid 1.286-96," SO 69 :

$72-82$.

Orlin, E. 1997. Temples, Religion and Politics in the Roman Republic. Leiden.

Papaioannou, S. 2005. Epic Succession and Dissension. Ovid, Metamorphoses 13.623- 14.528 and the Reinvention of the Aeneid. Berlin.

Pasco-Pronger, M. 2000. "Vates Operosus : Vatic Poetics and Antiquarianism in Ovid's Fasti," CW $93: 275-91$

--2006. Founding the Year : Ovid's Fasti and the Poetics of the Roman Calender. Leiden.

Putnam, M.C.J 1985. “Daedalus, Virgil, and the Ends of Art," AJPh 108 : 173-98.

Ross, D.O. 1975. Backgrounds to Augustan Poetry : Gallus, Elegy and Rome, Cambridge.

Salzman, M.R. 1998. "Deification in the Fasti and the Metamorphoses," in Deroux, ed., Studies in Latin Literature and Roman History 9, Collection Latomus 244 : 313- 46.

Schmitzer, U. 1990. Zetigeschichte in Ovids Metamorphosen : Mythologische Dichtung unter politischem Anspruch. Stuttgart.

Scott, K. 1941. "The Sidus Iulium and the Apotheosis of Caesar," CP 36 : 257-72.

Segal, C. 1969. "Myth and Philosophy in the Metamorphoses : Ovid's Augustanism and Augustan Conclusion in Book XV," AJPh 90 : 257-92.

--1999. "Ovid's Arcadia and the Characterization of Jupiter in the Metamorphoses," in Schubert ed., Ovid und Wirkung: Festgabe für Michael Von Albrecht zum 65. Frankfurt : 401-12.

--2001. "Jupiter in Ovid's Metamorphoses," Arion 9 : 78-99.

Simpson, C.J. 1977. “The Date and Dedication of the Temple of Mars Ultor," JRS 67 : 91- 94.

Smith, R.A. 1994. “Epic Recall and the Finale of Ovid's Metamorphoses," HV 51 : 45-53.

Solodow, J. 1988. The World of Ovid's Metamorphoses. Chapel Hill.

Syme, R. 1939. The Roman Revolution. Oxford.

Thomas, R. 1988. Virgil : Georgics vol. 1, Books 1-2. Cambridge. 
--2001. Virgil and the Augustan Reception. Cambridge.

Tissol, G. 1996. The Face of Nature : Wit, Narrative, and Cosmic Origins in Ovid's Metamorphoses. Princeton.

Wheeler, S. 1999. A Discourse of Wonders : Audience and Performance in Ovid's Metamorphoses. Philadelphia.

--2000. Narrative Dynamics in Ovid's Metamorphoses. Tübingen.

White, P. 1988. “Julius Caesar in Augustan Rome," Phoenix 42 : 334-56.

Wyke, M. 1992. "Augustan Cleopatras : Female Power and Poetic Authority," in Powell ed., Roman Poetry and Propaganda in the Age of Augustus. London : 98-140.

\section{NOTES}

1. The massive amount of scholarship devoted to the relationship between Ovid and Vergil is humbling. In most every book or article written on the Metamorphoses there is some mention of Vergil, so much so that one could almost perform a sortes Vergilianae. What follows is the most relevant and recent. Bömer 1959, Lamacchia 1960, Döpp 1969, Solodow 1988, 110-56, Hardie 1990, 1993, Tissol 1996, Smith 1997, Segal 1999, Papaioannou 2005. See Knox 1986, 6 and Hinds 1987, 14-23 also.

2. See Schmitzer 1990, 284-6 and Thomas 2001, 78-92. On Jupiter's speech "owing its very existence to another text, the speech of Jupiter in Aeneid 1" see Hardie 1997, 192-3. On Venus' desire to be head hancho of Olympus see Barchiesi 1999, 112-26.

3. For a recent and lucid discussion of Ovid's use of the Aeneid in Metamorphoses 15 see Feldherr 2010, 65-83.

4. I will not enter into the morass of the tone of Jupiter's prophecy in Aeneid 1. See most recently Julia Hejduk's discussion of Jupiter in the Aeneid (Hejduk 2010). My own reading of this passage will be filtered through Ovid, who, I think, clearly saw problems in including such prophecies on the historical events of Civil War.

5. It is notable, in this respect, that a poet like Horace, whose encomia are wholly at home in his conception of the Lyric tradition, rarely is mentioned in debates of Augustan/anti-Augustan. However, the merging of encomia with epic results in an ambivalence about the authenticity of such encomia because of broader narrative schemes of Epic impact one's rendering of the praise.

6. For a sophisticated and elaborate analysis of the Metamorphoses' narrative organization see Adamik 1999.

7. Wheeler 2000, 139. On deification in Ovid see Salzman 1998, 313-46.

8. Wheeler 2000, 139. See Segal 1969 for the theme of apotheosis in the Metamorphoses and its role in diminishing the claims of Caesarean deification.

9. Bettini 2008.

10. On Book 15 see Knox 1986, 65-83 and Wheeler 2000, 114-54.

11. It is notable that Myscelos, Pythagoras and Cipus all have claims to divine status as well, Myscelus in his capacity as oikistes, Pythagoras as a reincarnating entity, and Cipus as a potential emperor of Rome.

12. This connection between the Metamorphoses and Georgics has not received sufficient analysis and is a focus of my current research.

13. On the contested identification of this Caesar see O'Hara 1991, Kragerrud 1992 and their debate in SO 69 in 1994. See Dobbin 1995, 6-8 for a full discussion of the scholarly debate on these 
lines beyond O'Hara and Kragerrud. All arguments are anticipated by Austin 1971, 108-110. It is notable that Servius had no problem with this identification. I tend to follow Servius' reading.

14. As Dobbin 1995, 18-19 points out, Ocean could be interpreted as Britain, and as I show below, Ovid elaborates on this idea, but given the interplay between ocean and stars I think we are dealing also with imagined and hyperbolic peripheries.

15. For Egypt as part of Asia see Dobbin 1995, 16.

16. See Hardie 1997, 191-4 for succinct discussion of the acta, succession, and the disruptive role of Fama in mediating the transition of power.

17. The identification of this Caesar is contentious. Feeney 1991, 199 follows Due 1974, 71-2 in accepting the identification as Augustus, referring to the attempted "assassination" of the princeps in 23 (or 22) BCE. As such Feeney translates saevit 1.200 as "made their savage attempt," which seems to lessen the force of the verb. The identification really hangs on 1.204-5: nec tibi grata minus pietas, Auguste, tuorum/ quam fuit illa Iovi. As the lines develop, Julius Caesar is identified first, with Augustus to follow. But it is difficult to know if the pietas...tuorum refers to the senate, as it seems Due implies, or to the Caeserian faction after Caesar's assassination. Knox 1986, 17, rightly in my opinion, sees totusque perhorruit orbis as a reference to the litany of portents of the First Georgic in response to Caesar's assassination. For a full discussion of the "conspiracy" and attendant problems see Nisbet and Hubbard 1978, 151-8.

18. Hardie 1997, 193-5

19. Feldherr 2010, 71.

20. Cicero: de domo sua 39.9, 40.14; pro Sestio 135.14; de provinciis consularibus 43.4, 44.11, 45.17; Philippicae 1.16.11, 1.16.7, 1.16.9, 1.17.2, 1.18.11, 1.19.5, 1.19.7, 1.20.4, 1.23.4, 1.25.4, just to cite those uses of it in the first Philippic. The number of citations is large. Ovid: Amores 3.12.15 and Tristia 2.1.321.

21. The lines, quam sua progenies; neque enim de Caesaris actis/ ullum maius opus quam quod pater exstitit huius, while overtly referring to the acta of Julius Caesar, could (quite secondarily) be read as the acta of Augustus, with the implication that there was no other opus of the progenies greater than that his father became preeminent, i.e. deified and awarded the aedes Divi Iulii, a structure built by the progenies himself. The semantic range of exstare in this instance includes the existential meaning (OLD 4) if one interprets Caesaris as Julius or the idea of preeminence (OLD 2), if Augustus is understood. Ovid has translated into the Metamorphoses the ambiguity of Caesar... Iulius that has caused such consternation among scholars of the Aeneid, yet this ambiguity is a function of dynastic politics, not encomiastic poetics. Ovid illuminates the nature of this poetic ambiguity by offering the logic inherent in Vergil's thought, that Julius Caesar could not become Divus Iulius without his progenies and that his progenies could not have become a Caesar without his father's acta. See Pasco-Pronger 2007, 204 for a discussion of this adoption in the Fasti.

22. See, of course, Syme 1939, 112-22. Cic. Phil. 13.24, et te, o puer, qui nomini debes.

23. On Met. 15.750-8 see Hinds 1987, 24-6. Kraggerud $(1992,107)$ argued that the phrases imperium Oceano, fama qui terminet astris...spoliis Orientis onustum must refer to Augustus, "for the status of the world ruler stressed here should be an abiding one, not one soon cut off by violent death." He claims the spoliis Orientis onustum is temporally unrestricted, essentially referring to Augustus' future apotheosis, and that both lines read in tandem refer to $29 \mathrm{BCE}$, the year of Octavian's triple triumph (109). Following O'Hara, Dobbins (1995, 10-15) acknowledges that Augustus' victories could very likely be the referents of this phrase, but that Caesar is not precluded from being signified. While Kraggerud, I think, is right to assign $29 \mathrm{BCE}$ to the lines (if we must assign a date), O'Hara and Dobbins are right to suggest that the lines refer to Caesar. I would like to follow Allan Ball's argument made in 1913 and assert more forcefully that spoliis Orientis onustum refers to Julius Caesar alone. As Ball suggests, while Julius Caesar was deified in 42 BCE, it was not until 29 BCE that the aedes Divi Iulii was officially dedicated in the Roman Forum and decorated with the very beaks collected as spoils from the battle of Actium (see White 
1988, 337-8). Vergil is gesturing to the official consecration of the temple and its Actian associations. This interpretation has the benefit of clarifying the sense of aspera tum positis mitescunt saecula bellis since it refers to the period immediately after the dedication of the aedes Iulii Divi. It also lends further support to the idea that spoliis Orientis onustum describes Caesar in his official status as divinity within the topography of Rome while actually being "burdened" with the oriental spolia from Actium. To add Augustus into the mix needlessly confuses the sense, and Ovid himself in his reception of these lines could not be clearer that he interpreted Vergil's Caesar as referring to Julius alone.

24. These conquests are implicitly connected to deification. See Bosworth 1999.

25. Schmitzer1990, 281. While Bömer 1985, 457 is clearly right to attribute these lines to Caesar's touristic leisure trip with Cleopatra, the phrase victrices egisse rates, which he recognizes is without parallel, suggests Roman triumph.

26. It should seriously be considered whether the idea of Rome's seven hills is a direct response to the seven mouths of the Nile and seven gated Thebes. This could be understood as a type of imperial and national advertising campaign.

27. Schmitzer 1990, 280-1.

28. It is notable that the presentation of Caesar's assassination at Fasti 3.697-710 calls into question his own poetic authority in the Metamorphoses. See Pasco-Pronger 2007, 205-9 for a discussion of Caesar's apotheosis, Vesta and the election of Augustus (and future emperors) as pontifex maximus immediately before the ides of March. For fata in the Aeneid see Heinze 1915, 293-304.

29. For a succinct discussion of Met. 15.746-51 and his manipulation of "Vergilian speech" see Feeney 1991, 210-14, 218-19.

30. See Ahl 1985, 90-1 for the various and meaningful formations of Caesar Ovid manipulates in the death and apotheosis of Julius.

31. See Barchiesi 2001, 75 on the seamless insertion of Caesar's catasterism into the "fabulous fabric of preceding metamorphoses." Also Bömer 1985, 452.

32. See Barchiesi 1997, 194

33. See Gurval 1997 and Scott 1941. Gurval points out in the numismatic evidence an earlier star phase on the coinage of Octavian and a later comet phase during the principate proper (45). The sidus is found on many coin types from the reign of Caesar, through the triumviral period and into the principate, as Gurval nicely shows. It is claimed that this star is the sidus Iulium (a collocation used only once in Latin at Horace, Carmina 1.12.47).

A comet could be called a sidus, but it is often accompanied by a noun, adjective, or relative clause to mark it. Novum sidus, a rare collocation, is used only here of a comet. Vergil's Caesaris astrum is the first extent reference to Caesar's star (Eclogue 9.47). novum sidus is found in only two other contexts, Georgics 1.19 where Augustus is free to choose his celestial locus and Curtius Rufus' Historiae 10.8.23.4 in an unclear context. There are a number of potential interpretations for this doubling; perhaps Ovid is referring to the change of the Iulium sidus over time from star to comet (Gurval's interpretation, 69); he could be motivated by statues of Caesar with a star affixed to his head, which he might be alluding to with stella comans; he could be depicting a twofold process whereby his ascension is in the form of a comet and his final form is a star. See Gurval 1997, 62-69 for a discussion of Caesar as star including this passage.

34. In particular see Knox 1986, 65-81.

35. On the Lock of Berenice and Caesar's apotheosis see Knox 1986, 76-9. Knox rightly emphasizes the influence of Callimachus and Ennius on the entire organization of Book 15. Barchiesi 1999, 117.

36. Barchiesi 1999, 117-19. Barchiesi also shows that Bion's Epitaph to Adonis and Theocritus 15.105-7, which depicts Aphrodite anointing Berenice, further impacts our reading of Venus' lament of Caesar here. 
37. The metaphor might be extended to Ovid whose apotheosis comes through os populi, as if the head now has a mouth. It is also notable that Caesar himself was bald. Rome, like Caesar, also loses its hair.

38. Wyke 1992, 103.

39. Wyke 1992, 102.

40. Clearly, the tabularia are a response to Jupiter's unrolling a scroll of fata in the Aeneid (see Wheeler 1999, 56 following Austin).

41. On the connection between these fata, the Aeneid, and Jupiter's knowledge see Barchiesi 2001, 131.

42. On the materiality of tabulae and much else see Meyer 2004.

43. See Smith 1994, 50.

44. Due 1974, 86 suggests that "the invention of a rerum tabularia is on the same level as the Palatia caeli."

45. Wheeler 1999, 56-57 comments on the close and antithetical connection between the House of Fame and the fata. He suggests that the "living voice of fama" representing "poetic tradition and authority in terms of the hazards of oral communication" stands in marked contrast to the fixed inscriptions of fata, which are no longer spoken but read, and as a result are immutable. The problem with this analysis is that Ovid's tabularia are themselves a response to tradition, noted by the mass of forms of ferre that have peppered the lines, and in addition their sudden, unexpected, and wholly untraditional appearance at this moment in the text suggests that the fama and fata are moving towards the same telos. It is notable that the Metamorphoses, like the tabularia, are not vulnerable to the fulmen of Jupiter (Iovis ira 15.871), as mentioned in Galinsky 1975 , 254. Hardie's discussion on fama, fata and nepotes $(1986,369-70)$ is closer to the type of associations at work in the Metamorphoses. Ovid has collapsed the distinction between fama and fata by the end of the epic.

46. See Barchiesi 2009 and Gladhill 2013.

47. I believe an argument can be made that these topographical markers suggest that the entire Metamorphoses never leaves Rome via the experience of art and landscape within the city. From this point of view the Metamorphoses, like the Aeneid, is a foundation tale of Rome as a center of art.

48. Thomas 1988, 256 comments on the oddity of ferreus modifying iura when bronze was the metal of choice for inscription. Iura imply an Age of Iron.

49. This point is in contrast to Segal 2001, 90 who sees this episode of the Metamorphoses in the following way: "Ovid is comfortably within the limits of familiar praise of Augustus' moral program, and he is drawing on the Virgilian Jupiter's famous prophecy of the Augustan Golden Age in Aeneid 1.286-96."

50. Amores 3.8.45-52. See Holleman 1969, 47-8.

51. I wonder if Ovid is making broader argument about the Ages of Mankind in the Metamorphoses as a whole. It is notable that this focus on narratives of decline looks back to the Ages of Metal at the beginning of the Metamorphoses. It is also significant that Jupiter destroys Iron Age people with a deluge. When Deucalion and Pyrrha create people out of stones, this could be understood as the beginning of the "Stone Age." The first sign of this Stone Age is the incrimination of the gods in "Iron Age" behavior on the human plane. From this point of view the apotheosis of Caesar is not an ascension of a man, but the degradation of Gods.

52. hic sua conplevit, pro quo, Cytherea, laboras,/ tempora, perfectis, quos terrae debuit, annis./ ut deus accedat caelo templisque colatur,/ tu facies natusque suus, qui nominis heres/ inpositum feret unus onus caesique parentis/ nos in bella suos fortissimus ultor habebit. (Met. 15.816-21). It is suggestive that the language of biological birth in the voice of the poet does not correspond to the language of hereditary titles in the voice of Jupiter in his remembrance of the fata. 
53. Syme 1939, 471. See also Pasco-Pronger 2007, 276-85 on Ovid's treatment of the ultor-theme in the Fasti and the debate over whether the vow of vengeance happened at Philippi or was part of Augustus' Parthian strategy. The vow at Philippi could very well date to 2BCE (Pasco-Pronger, 279-80). Ovid is the earliest source of Octavian's vow at Philippi in 42 BCE as Pasco-Pronger notes (276).

54. Due 1974, 86-7. Due (87) states, "Vergil and Horace pass over Mutina in complete silence. Obviously Augustus did not want it to be remembered too well that one of his first allies was at the same time one of his father's murderers. It was best to say as little as possible about Mutina. The distortion here is apparently meant to put Augustus in the best light, but it is so evidently a distortion that it becomes its own corrective--and that may be the point. The flattery goes so far that it must have had an embarrassing effect." See also Maleuvre 96, 1991.

55. at quicumque negas ausi, prohibente deorum/ numine, polluerant pontificale caput,/ morte iacent merita: testes estote, Philippi,/ et quorum sparsis ossibus albet humus./ hoc opus, haec pietas, haec prima elementa fuerunt/ Caesaris, ulcisci iusta per arma patrem. See Pasco-Pronger 2007, 205-5 on Mars Ultor in the Fasti. She discusses both this passage and Fasti 5.573-75, the very moment young Octavian vows the temple.

56. On the dating of the dedication of the temple see Simpson 1977.

57. Met. 15.829-31 (quid tibi barbariam gentesque ab utroque iacentes/ oceano numerem? quodcumque habitabile tellus/ sustinet, huius erit: pontus quoque serviet illi!) rewrites both the imperium Oceano of Jupiter's prophecy in the Aeneid 1 as well as Ovid's listing of Caesar's conquests that span aequorei Britanni and Pontus in Metamorphoses 15.

58. See Due 1974, 70 on Ovid's contemporary Rome already marked as Iron in the ages of metal. It must be remarked that this claim between ferre and ferrum would be more than inconclusive if the end of the Metamorphoses were not so bound up with the notion of the Iron Age.

59. The mass of material compiled by Ahl 1985 lends support for this assertion. He does not discuss these particular cases.

60. Of course, given that iustissimus derives from ius, perhaps the superlative emphasizes even more an Iron Age under Augustus. Vergil's ferrea iura may be important here.

61. Iubar is, of course, another etymological marker of Caesar, as noted by Ahl 1985, 90.

62. It is notable that this is the first metamorphosis that characterizes change in terms of the soul rather than the body. In particular, this metamorphosis focuses on the separation of the anima from the corpus, itself the standard definition of death from Plato onwards. This is the one metamorphosis in which the corpus is absent from the transformation, suggesting a break from the theme of nova corpora. This suggests that tales of nova corpora have come to an end as metamorphosis is now a matter of the spirit.

63. See Barchiesi 2001, 76-8.

64. For problematic associations in comparing Caesar-Augustus to these heroes (especially the Atreids) see Holleman 1969, 49-51, Ahl 1985, 89 and Salzman 1998, 333-4.

65. Di, precor, Aeneae comites,...dique Indigetes genitorque Quirine/ Urbis et invicti genitor Gradive Quirini,/Vestaque Caesareos inter sacrata Penates/ et cum Caesarea tu, Phoebe domestice, Vesta (15.861-65)

66. di patrii Indigetes et Romule Vestaque mater,/quae Tuscum Tiberim et Romana Palatia seruas,/ hunc saltem euerso iuuenem succurrere saeclo/ ne prohibete. satis iam pridem sanguine nostro/ Laomedonteae luimus periuria Troiae;/ iam pridem nobis caeli te regia, Caesar,/ inuidet atque hominum queritur curare triumphos,/ quippe ubi fas uersum atque nefas: tot bella per orbem,/ tam multae scelerum facies, non ullus aratro/ dignus honos, squalent abductis arua colonis,/ et curuae rigidum falces conflantur in ensem./ hinc mouet Euphrates, illinc Germania bellum;/ uicinae ruptis inter se legibus urbes/ arma ferunt; saeuit toto Mars impius orbe,/ ut cum carceribus sese effudere quadrigae,/ addunt in spatia, et frustra retinacula tendens/ fertur equis auriga neque audit currus habenas.

67. On this prayer and its appropriateness see Wheeler 2000, 146-7. 
68. Newman 1967, 112 reads Ovid's praesagia vatum as a testament to the fact that he does not "really understand the vates-concept at all." Clearly, he has understood it all too well.

\section{RÉSUMÉS}

The purpose of this paper is to provide an analysis of the poetics of Ovid's reception of Jupiter's prophecy in Aeneid 1 and to discuss the implications of Ovid's engagement with Vergil. At the end of the Metamorphoses Ovid is interested in exploring the role of Vergilian prophetics in epic from a perspective that channels all the ways Vergil utilized fate, prophecy and divination into an ironic authorization of an Augustan present on the verge of ending. Whereas the Aeneid ends with the interpretative crux of the meaning of Turnus' death, Ovid's epic concludes with the imminent death of Augustus and the interpretative void his absence creates.

INDEX

Mots-clés : Aeneid, Deification and Poetics., Fate, Metamorphoses, Prophecy 